\title{
Quality of Corporate Governance Risk Management in Dealing with Unanticipated Events: Evidence from Pakistan
}

\author{
Rubeena Tashfeen*, Saud Hayat ${ }^{* *}$, Afreen Mallik ${ }^{* * *}$
}

\begin{abstract}
This study examines the effectiveness of the corporate governance structure when coping with any potentially unexpected events. For the purpose of this research, an event study has been conducted in order to investigate the market responses of various firms through the Cumulative Average Abnormal Return (CAAR) of the stocks listed on the Pakistan Stock Exchange (PSX). The stocks data under consideration is that which was presented after the assassination of Benazir Bhutto in 2007. The overall results indicate that firms that are governed conventionally do not perform well in the markets during a crisis situation. In our comparison of conventionally, and non-conventionally governed firms, the overall pooled results show that the former record a lower CAAR. This, in short, indicates that conventional corporate governance structures may not be equipped to take timely and dynamic actions that are deemed necessary in the face of a crisis. Moreover, our results suggest that firms which have less diversified ownership, and governance mechanisms are less vulnerable to such unanticipated events. There are two reasons that support our hypotheses: first, strict governance mechanisms, and a resultant cautious/conservative approach may not allow firms to take timely and proactive decisions during these situations and second, there is a lower chance of existing agency problems, as family owners would be working for the protection of their own wealth during these events. Therefore, our findings ultimately reveal that the conventional corporate governance structures that work during normal time period, may become ineffective during a crisis. This study, aims to fill a gap in the literature in order to provide fresh insights into the stock market dynamic, and corporate governance risk management. Furthermore, it also highlights the benefits of family owned structures, and unconventional corporate governance systems, that may outperform conventional governance structure in some situations. This, however, raises the question whether one governance framework could be the correct fit in all the situations.
\end{abstract}

Keywords: CAAR, Corporate Governance, Pakistan Stock Exchange, Risk Management.

\footnotetext{
* Associate Professor, University of Central Punjab, Lahore, Pakistan.

** MS Candidate, University of Management and Technology, Lahore, Pakistan.

*** MS Candidate, University of Management and Technology, Lahore, Pakistan.
} 
JEL Classification: G30, G32; G34.

\section{Introduction}

Over the years, global and national events across the world have proved to be fatal for stock markets. Many researchers have examined the extent to which certain events can impact stock markets. In this regard, their findings have revealed that events such as the 9/11 attacks, London attacks, 2008 global financial crisis, and other global phenomenons and critical events have had a severe impact on stock returns (Ali, Qingshi, Memon, Baz, \& Ali, 2017). Similar research has also been done in Pakistan, where authors have studied notable national events and situations, such as Benazir Bhutto's assassination, the long march in 2007, ouster of General Pervaiz Musharraf, the elections of 2008, and the various terrorist attacks (Hassan, Mahmood, Ahmed \& Abbas, 2014). Researchers define the events as either anticipated or unanticipated. for instance, if certain happenings cannot be predicted, for example, Benazir Bhutto's assassination, the 2008 Global Meltdown, or the ouster of a dictatorial government in 2008, then these are termed as unanticipated events that have the tendency to leave severe impacts on the unprepared financial markets (Barros \& Gil-Alana, 2009).

Corporate governance is one of the most critical concepts considered whenever the matter of corporate performance and shareholder rights arises. It has been argued that the action and process of decision making varies across firms, based on their corporate governance mechanisms and composition. In the global financial crisis of 2008, one of the key factors that contributed in the global meltdown was corporate governance (Erkens, Hung, \& Matos, 2012; Kirkpatrick, 2009). Earlier, many firms in the US, such as Enron and World.com, faced bankruptcy due to fraudulent activities and weak corporate governance. This necessitated significant governance reforms throughout the world. In response, countries have now established corporate governance codes which require firms to implement well-defined governance frameworks and mechanisms, in order to ensure the proper management of companies that are aligned to the interest of stockholders.

Stock markets are highly sensitive to the events that take place in the financial markets. A catastrophic event in the market can leave investors and organizations in ruins, as has been evidenced during the global financial crisis. Traditionally, researchers have been employing event specific study tools to analyze the effects of the particular event on the stock earnings (Cumulative Average Abnormal Returns), herein after 
CAAR. But their models were limited to the examination of abnormal returns for the days surrounding an event. Our paper extends the methodology of the event study, and establishes an innovative framework. We determine the impact of the Benazir Bhutto's assassination on CAAR, for the PSX stocks. Secondly, and more importantly, our contribution is in the examination of the impacts of conventional and unconventional corporate governance structures on CAAR, specifically in response to Benazir Bhutto's assassination. This paper distinguishes itself from other event studies, as it provides new insights into the performance of firms during an event, and provides new evidence on corporate governance framework and structures during a crisis.

The next section presents the research objectives of this research, followed by the literature review. The fourth section documents the research methodology employed, along with the dilation on the sample data and description of variables. In the fifth section, we provide results of the tests, followed by a discussion of the findings and conclusion of the study.

\section{Research Objectives}

The larger research objective of this study is to gauge the effectiveness of corporate governance structures: Conventional and unconventional, during crises. And towards the end, we aim:

a) To study the impact of Benazir Bhutto's assassination event on the cumulative average abnormal returns of the PSX stocks, and,

b) To examine the impact of the corporate governance structure on the CAAR of stocks during the days surrounding the event.

\section{Literature Review}

Since the governance crisis of 2001-2003, there have been efforts to bring positive reforms and improvements to the existing standards, through the definition of new regulations to protect shareholders' wealth and organizational sustainability. However, efforts such as Sarbanes Oxley Act (SOX 2002) in the US, and European corporate governance codes still appear to be inadequate as evidenced during the financial crisis of 20072008. Many researchers have related the magnitude of losses to the hubris and greed of the management, and poor corporate governance. A statement from an OECD report insists that "the financial crisis can be, to 
an important extent attributed to failures and weaknesses in corporate governance arrangements" (Kirkpatrick, 2009, p. 2).

While conducting a cross country study on the impact of governance over the performance of European banks during credit crisis, Beltratti and Stulz (2009) argued that they found no evidence of better performance of banks with better governance. They employed the universally accepted Corporate Governance Quotient (CGQ score) method to gauge the governance score. The findings indicated that commercial banks which had directors who enjoyed more independence, and where the shareholders tended to favor the board, suffered the most during the financial crisis of 2007-08. Adams and Mehran (2010) too documented that the ratio of outside directors is irrelevant to firm performance.

Erkens et al. (2012) tried to gauge the influence of corporate governance on the returns of financial firms exclusively during the financial crisis in 2007-08. They obtained data from 30 countries, and their sample constituted of 296 firms from the financial sector. The study found that financial institutions which had a high number of independent directors on their boards, and a high concentration of institutional ownership, had their returns more adversely impacted during the financial crises. They contended that this was because of two main factors: firstly, institutional ownership encouraged the maximization of returns, even at the cost of a higher risk factor; and secondly, independent directors insisted on investing in risky projects, just to maximize the shareholders' wealth.

There is limited research done and available on the impact of corporate governance on the response of the stock market to unanticipated events in Pakistan. Javid and Iqbal (2008) address the effects of corporate governance on corporate valuation, ownership and corporate financing in Pakistan. Furthermore, the authors also examine the determinants of corporate governance and investigate whether more concentrated boards, ownership, external financing, firm size, and project opportunities have any relationship with the strength of corporate governance. Their findings suggest that it is eventually the financial markets that compensate good governance and punish bad corporate governance practices. Firms with high growth and a larger size tend to require more external financing and as a result, they tend to choose better governance standards and practices, and a higher level of transparency. On the other hand, firms with concentrated ownership do not tend to adopt good governance practices and also prefer to disclose less. On the contrary, Carney (2005) and Anderson and Reeb (2003) argue that when there is higher family 
ownership and firms experience less agency issues. They claim that family owners certainly do have more rights over assets and hence, they are more active in making a decision, given the time constraint of an opportunity that might have the potential to materalise. This gives them a competitive edge over other rival firms.

In another study, Hassan et al. (2014) examined the responses of KSE 100 index returns to political events through the years 1998 to 2013. They calculated the abnormal returns to measure the market responses and employed the event study methodology for this purpose. As a part of their study, they recorded the adverse abnormal returns a few days prior, and a few days post the occurrence of an event for every outcome window that was examined. Nazir et al. (2014) also studied the impacts left by political events on abnormal returns for the years between 1999 and 2011. They employed the mean-adjusted return model to examine the stock return responses through the event study. The main objective was to study the difference in returns due to certain political regimes i.e., autocracy and democracy. The authors contended that Pakistani stock markets are very sensitive to political upheavals, with the KSE 100 listed companies recording negative returns post political crisis event. At the same time, the study also observed the Karachi Stock Exchange's inefficiency, as the market started absorbing the strident information only 15 days after the event. Since there have been fewer dictatorships in comparison to civilian government, the authors were not in a position to make any inferences on stock market responses during the autocratic government style.

Another study was conducted by Taimur and Khan (2015) on the effects of political events and natural disasters on Pakistan KSE 100 stock market, by conducting a research on almost 43 government specific, and four disastrous occurrences from the years 1998 to 2013. The authors classify political events into two parts: a) encouraging political events; and b) negative government occurrences. By using different event windows, they inferred that the catastrophic happenings have had no effect on stocks returns, whereas negative political occurrences unfavorably have affected the returns of listed firms on Pakistan stock markets. Suleman (2012) conducted a similar study, but used the univariate asymmetric GARCH methodology in order to fulfill his research objectives. The purpose of his research was to measure the impact of any political news on the stock market through the variability of stock market returns. The findings indicated that the industries or sectors which tend to be highly volatile in response to good news, tend to have lower beta and variances that change rapidly over time. 
Recently, there has been a growing awareness of the disadvantages of conventional governance structures, mandated under the codes of corporate governance. Researchers and industrialists are questioning whether family dominated governance structures, with less independent directors, have some advantages over the conventional type of framework. Warren Buffet questions whether any director can be totally independent when it comes to the compensations pertaining to the the board of directors. In this part of the continent (India and Pakistan) there are promoter-driven companies, where the boards may not be able to achieve independence. Recently, the Tata and Mistry conflict has highlighted the need to revaluate the corporate governance structures and control mechanisms, especially with regard to independence. Others are questioning whether the conventional type of corporate governance can adequately manage and control the very large conglomerates, where numerous layers of hierarchies exist (Livemint, 2017).

The fact is that the current model of corporate governance, itself, has been challenged at many forums, particularly for family owned businesses. The requirements of management of family owned business, and their governance structures are perceived to be different than the standard model of corporate governance.

Our research mainly focuses on the variability of cumulative abnormal returns during the biggest political/terrorist events that took place in the history of Pakistan, and caused turmoil and panic amongst the public and investors who were relying on the stock exchanges. We examine the governance structures prevalent in the KSE listed companies at the time of the event, in order to assess their role during the crucial event. The objective of this study would be to determine whether conventional governance structures provided a cushion to companies during the crisis. This is the first study to make such examination, both in Pakistan and internationally, and we have aimed to contribute to the field of corporate governance, and also add depth to the literature pertaining to the studies of finance.

\section{Methodology}

Event studies have popularly been used to test the stock market efficiency in the literature pertaining to finance. The objective of this tool is to see what effect an event can have on returns or firm performance. There are generally two types of events that can be examined: Anticipated and unanticipated events. Events which can be predicted, or are predetermined fall within the category of anticipated events, such as dividend 
announcements, merger announcements, acquisitions, and joint ventures. Unanticipated events, on the other hand, occur suddenly and without any prior information of the event. They can have catastrophic effects such as, the 2008 global financial crisis, terrorist attacks, natural disasters, etc. Brown and Warner (1985) have elaborated in great detail on the methodology of constructing an event model, where the variable of interest is to be examined, both before and after the occurrence of the event.

We follow the methodology of Brown and Warner (1985) in developing our model. The main event to examine in this study is the event of the assassination of Benazir Bhutto (a two-time serving former primeminister of Pakistan), that took place on 27th December, 2007. The reason behind studying Benazir Bhutto's assassination event is that it was one of the most catastrophic events in the political history of Pakistan, having drastic economic consequences as well. Generally, in order to study the effects of an event on firm earnings, researchers resort to the examination of abnormal returns as the indicators of the firm's earnings. There are a few studies that examine the CAAR, and have largely observed a negative CAAR for the event. The primary focus of this research is to examine the CAAR for the event with respect to the impact that corporate governance has during the occurance of unanticipated events or crises.

\subsection{Data}

The data has been collected from the annual reports of the companies that are part of the study sample. The "event" that is taken into consideration for the purpose of this research constitutes of a single event, which was the assassination of Benazir Bhutto. In this regard, the data has been extracted from 45 firms, listed on the stock exchange. We have considered the top $10 \%$ of the firms, under each sector on the PSX, based on their market capitalization. Currently, there are almost 584 listed companies operating on the Pakistan Stock Exchange, belonging to approximately 36 sectors. However, it was observed that there were firms from certain sectors whose data was not available, and hence, these were excluded from the study sample.

This study employs both corporate governance, and data pertaining to abnormal returns. For the purpose of reviewing the abnormal returns, the market price of the shares were taken prior to the event date. Usually, the event studies take a term horizon of 220 or 240 days returns before the event, in order to calculate the expected returns or the estimation window. We have calculated expected returns using a horizon of 260 days 
returns. Moreover, by using the method proposed by Kothari and Warner (2007), we have calculated the expected returns through the market model, by regressing each stock's historical return on the markets return. Corporate Governance data pertaining to corporate governance characteristics, i.e., Big-4 auditors, family ownership, foreign directors, independent directors, block holders, and CEO \& chairman duality, were extracted from the annual reports manually.

\subsection{Corporate Governance Variables}

A distinguishing feature of this paper is the examination of CAAR, based on the corporate governance components. We have segregated the governance structures into the conventional and unconventional, where the mandatory requirements under the code of corporate governance are termed as conventional corporate governance. Any governance composition that deviates, and is different from the conventional structure, is termed as unconventional governance. To add to this, we have followed Lang's and Maffte's (2011) method in our distinction between the two groups. The authors have studied the transparency of the stocks during the 2008 global meltdown, and classified firms into highly transparent, and those with low transparency, using an index. We have also segregated the corporate governance variables into conventional and unconventional variables, and examine the components: Big-4 audit firms, foreign directors, family ownership, independent directors, institutional ownership, block holders, and CEO/Chairman duality.

Javid and Iqbal (2008) studied the impact of the ownership concentration, and the performance of the KSE stocks. They argued that firms in developed economies are dominated by ownership characteristics i.e. lower family ownership, higher independent directors, higher institutional ownership, and lower block holders. Some authors also suggest that firms with less ownership concentration are more proactive in their decision making processes, in wake of thee unanticipated events that might occur (Feinberg, 1975). The corporate governance mechanisms are developed based on the classifications shown in Table 1.

Table 1 shows the composition of the governance mechanisms. BIG-4 audit firms are taken as the dummy variable, and rated conventional if the firm has external auditors from BIG-4 or " 0 " otherwise. Foreign directors is also taken as a dummy variable representing the conventional governance if there are foreign directors in the BOD. Family ownership is measured as the percentage of the shares held by the family members, 
indicating conventional governance if family holdings are below the mean of the overall sample. Similar measures are taken for independent directors, and institutional ownership. CEO/Chair duality is also taken as a dummy variable, and is labeled as conventional governance, if both positions are not held by the same person. Lastly, block holders are measured as the number of block holders in a firm.

Table 1: Segregation of Corporate Governance Mechanisms

\begin{tabular}{lccccc}
\hline Variable & Measure & $\begin{array}{c}\text { Conventional } \\
\text { Governance (1) }\end{array}$ & \multicolumn{2}{c}{$\begin{array}{c}\text { Unconventional } \\
\text { Governance (0) }\end{array}$} \\
\hline BIG4 & Dummy & Yes & 1 & No & 0 \\
FORDRC & Dummy & Yes & 1 & No & 0 \\
FAMOW & Mean & $<$ Mean & 1 & $>=$ Mean & 0 \\
CEO/CHR & Dummy & If duality & 1 & If no duality & 0 \\
INDDRC & Mean & $>=$ Mean & 1 & $<$ Mean & 0 \\
INTOW & Mean & $>=$ Mean & 1 & $<$ Mean & 0 \\
BLOCK & Mean & $<$ Mean & 1 & $>=$ Mean & 0 \\
\hline
\end{tabular}

Variable definitions are provided in Appendix 2

\subsection{Event Design}

The event study is designed using the work of Kothari and Warner (2007). It is based on a short horizon, as we have taken into consideration the first 20 days in the post-event window, since the stock markets show sensitivity (though diluted) to events up to the $20^{\text {th }}$ day, but the effects disappear after this..

Figure 1: Model of Event Study

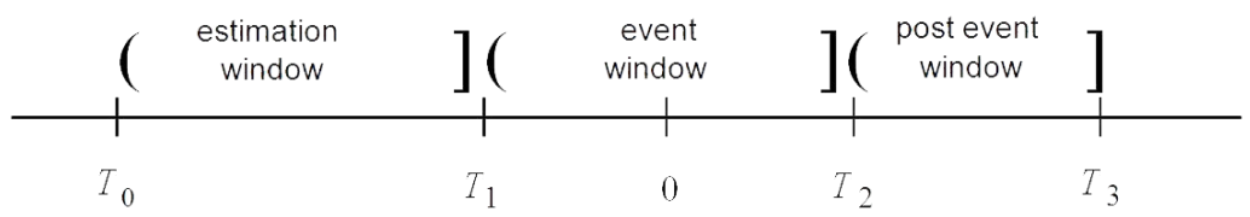

The above figure shows the model of our event study, where the ' $\mathrm{T}_{0}$ ' represents the beginning of the estimation window, i.e. one year prior to the event window, and ' $T_{1}$ ' as the end of the estimation window. Whereas, ' 0 ' is the event date i.e., the day that Benazir Bhutto was assinated, lies between ' $\mathrm{T}_{1}$ ' and ' $\mathrm{T}{ }^{2}$ ', and this event window is based upon a single day for the event which took place on 27th December, 2007. The post-event window that lies between ' $T_{2}$ ' and ' $T_{3}$ ', comprises of the 20 days after the event, and it is our 
focus of interest for the purpose of this study. The detailed methodology for estimating the CAAR is provided in Appendix 1.

\section{Results}

Based on the techniques described in the works of Kothari and Warner (2007), we have run the market model to derive the abnormal returns for the stocks. Subsequently, we have also computed the CAAR from the abnormal return of stocks for the pooled sample for each day, starting from day 0 as the day of the event. In order to meet the objectives, conventional and unconventional governed firms are distinguished in the way that Lang and Maffte (2011) guided in their research papers. The description of the governance variables is provided in Appendix 2. Furthermore, we have segregated the CAAR for the stocks by splitting the sample based on conventional and unconventional corporate governance. The results of a comparison between the mean CAAR for pre-event and post-event periods are presented in Table 2.

Table 2: Mean CAAR for Firms with Conventional and Unconventional Governance

\begin{tabular}{lcccc}
\hline & \multicolumn{2}{c}{ Pre-Event } & \multicolumn{2}{c}{ Post-Event } \\
\hline Pooled & \multicolumn{2}{c}{0.5032835} & \multicolumn{2}{c}{-0.1245758} \\
\hline & Conventional & Unconventional & Conventional & Unconventional \\
\hline Pooled & 0.0770744 & 0.0429811 & -0.0052917 & -0.0178909 \\
BIG4 & 0.2639915 & 0.239292 & -0.1306628 & 0.0060871 \\
FRDR & 0.2831761 & 0.2201074 & 0.0649133 & -0.1894889 \\
INDR & 0.0505098 & 0.4527737 & -0.0924687 & -0.032107 \\
FMOW & 0.2701282 & 0.2331553 & -0.2283304 & 0.1037548 \\
INOW & 0.1724838 & 0.3307997 & 0.0137473 & -0.138323 \\
BLOCK & 0.1758976 & 0.3273859 & -0.1115695 & -0.0130061 \\
CECH & 0.2842668 & 0.2190167 & -0.0024229 & -0.1221527 \\
\hline
\end{tabular}

The above Table 2 shows the mean values of CAAR for the pooled and grouped samples. The firms are divided into two groups; conventional and unconventional, based on their governance structure. The CAAR for the pooled sample drastically drops below zero during the post-event days. The grouped sample mean differences present a different picture. The mean CAAR for the conventional governed firms was higher to those of unconventional governed firms $(0.0770$ and 0.0430$)$ in the pre-event days, and as well as in the post-event days (-0.0053 and -0.01790). The BIG4 auditors show a higher CAAR during the pre-event days. Although the results drastically changed in the days following the assassination, as the firms having auditors other than Big-4 (0.0060) performed far better than 
those firms using Big- 4 auditors (-0.1306). When looking for representation of foreign directors in the BOD, we find that firms with foreign directors performed better than those which had no representation of foreign directors, and this difference persists in both the pre-event and post-event days. Firms with more independent directors in the BOD were more vulnerable to the event, as their abnormal returns were low compared to firms with less independent directors. Firms with higher family ownership, and larger institutional ownership show higher CAAR values after the event. Furthermore, firms with a larger number of block holders appear to have done better than those with a lower percentage of block holders; and the CEO \& Chairman duality provides higher CAAR values after the event.

Table 3 provides a summary of the final results that are computed by running Levene's test of the equality of variances, and a two sample ttest for equality of means. The detailed results of the tests are provided in Appendix 3. We determine whether the post-event CAAR for the Pooled sample is statistically different from the estimation window or not. The results suggest that the post-event CAAR is statistically different between firms which have unconventional and conventional governance. However, the CAAR recorded is negative. Secondly, for the pooled and grouped samples, we have run tests to see if the two groups (conventional and unconventional governance), are different from each other in both their mean performance and variance. The pooled sample, which was divided into conventional and unconventional governed firms, shows that these firms are significantly different from each other. However, the results for differences in CAAR variances for the BIG-4, family ownership, $\mathrm{CEO} /$ Chairman duality, foreign directors, independent directors, and institutional shareholding are significantly different.

An analysis of the two sample t-test of equality of means shown in Table 3 depicts that there is a difference in the mean CAAR performance for the two groups: conventional governance and unconventional governance. While all the results are statistically significant, the Pooled sample, Big-4, independent directors, family ownership, and block shareholding exhibit higher mean CAAR values for the unconventional governance group. 
Table 3: Mean CAAR differences for post-event Days

\begin{tabular}{lcc}
\hline & Mean CAAR & t-statistic \\
\hline Pooled & -0.02437 & $-3.109^{* * *}$ \\
\hline Pooled & $\begin{array}{c}\text { Mean Difference Governance } \\
\text { Conventional (G) - Unconventional (P) }\end{array}$ \\
BIG-4 & -0.71517 & \\
FRDR & -0.13072 & $-8.29^{* * *}$ \\
INDR & 0.25156 & $-5.919^{* * *}$ \\
FMOW & -0.6181 & $9.84^{* * *}$ \\
INTOW & -0.33944 & $-2.376^{* * *}$ \\
BLOCK & 0.15895 & $-10.13^{* * *}$ \\
CECH & -0.10974 & $6.25^{* * *}$ \\
\hline
\end{tabular}

Pooled CAAR are highly statistically significant for all the days considered in the post-event window. We have run a two-sample t.test to determine if the grouped samples (conventional and unconventional) are statistically different from each other. ${ }^{* * *},{ }^{* * * *}$ show the significant $p$-levels at $1 \%, 5 \%$ and $10 \%$ respectively.

The differences in governance control mechanisms for conventional and unconventional structures are highlighted graphically in Figures 2, 3, 5, 6, and 8, respectively shown below. The foreign directors, institutional ownership and CEO/Chairman duality show higher CAAR mean values for the group with conventional governance, which is demonstrated in Figures 4, 7 and 9, respectively.

Figure 2: Cumulative Average Abnormal Return (CAAR) for Conventional (GCG) and Unconventional (PCG) Corporate Governance Sample Firms

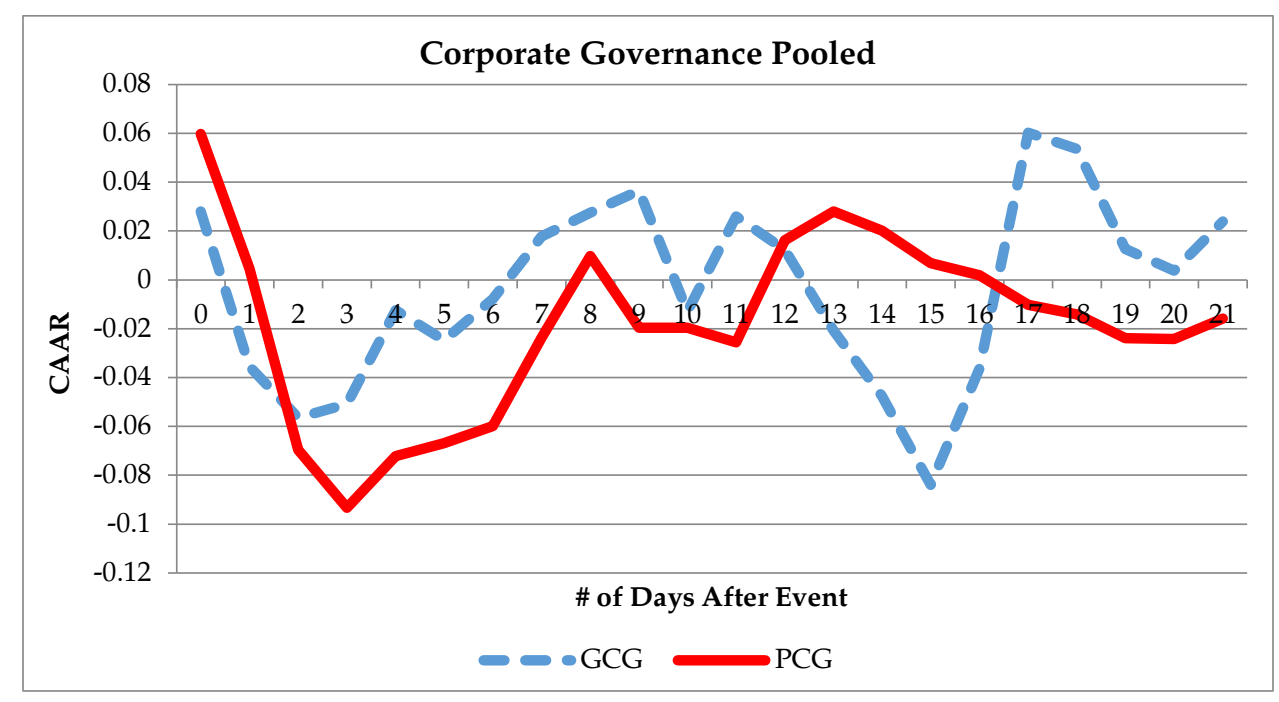


Figure 3: CAAR for Firms that use Big 4 Auditors (BIG-G) and Non-Users (BIG-P)

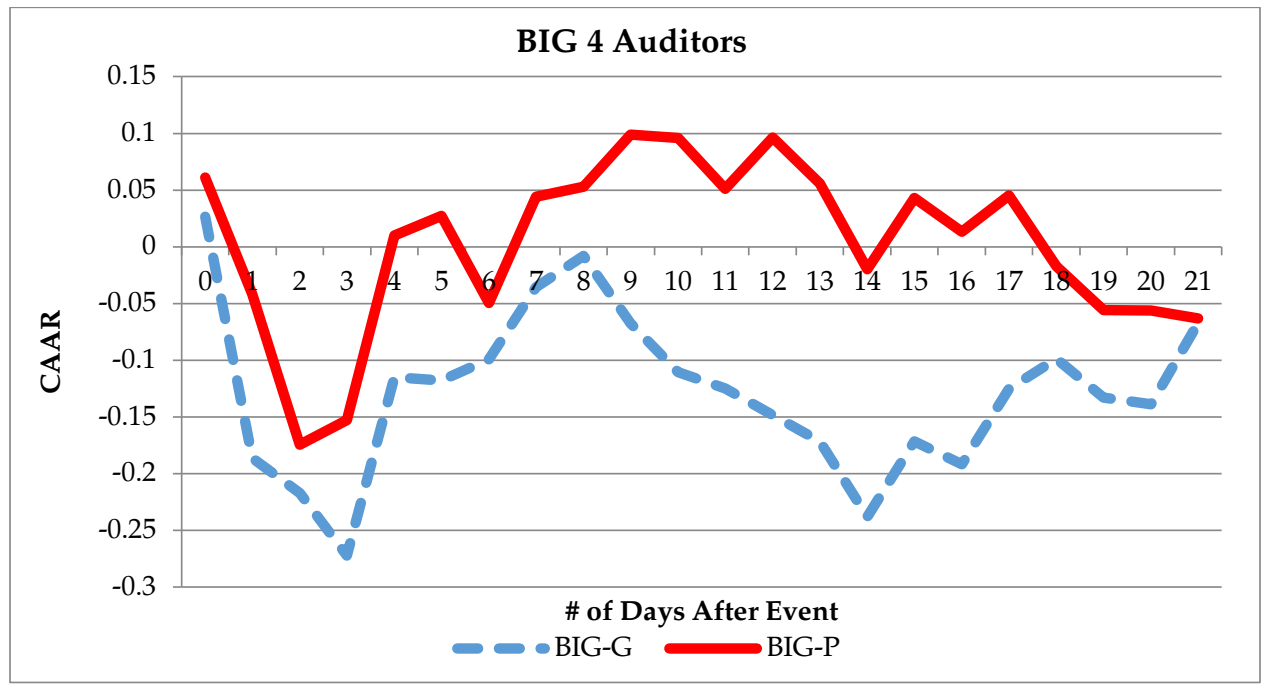

Figure 4: CAAR for Firms with (FRDR-g) and without (FRDR-P) Foreign Directors

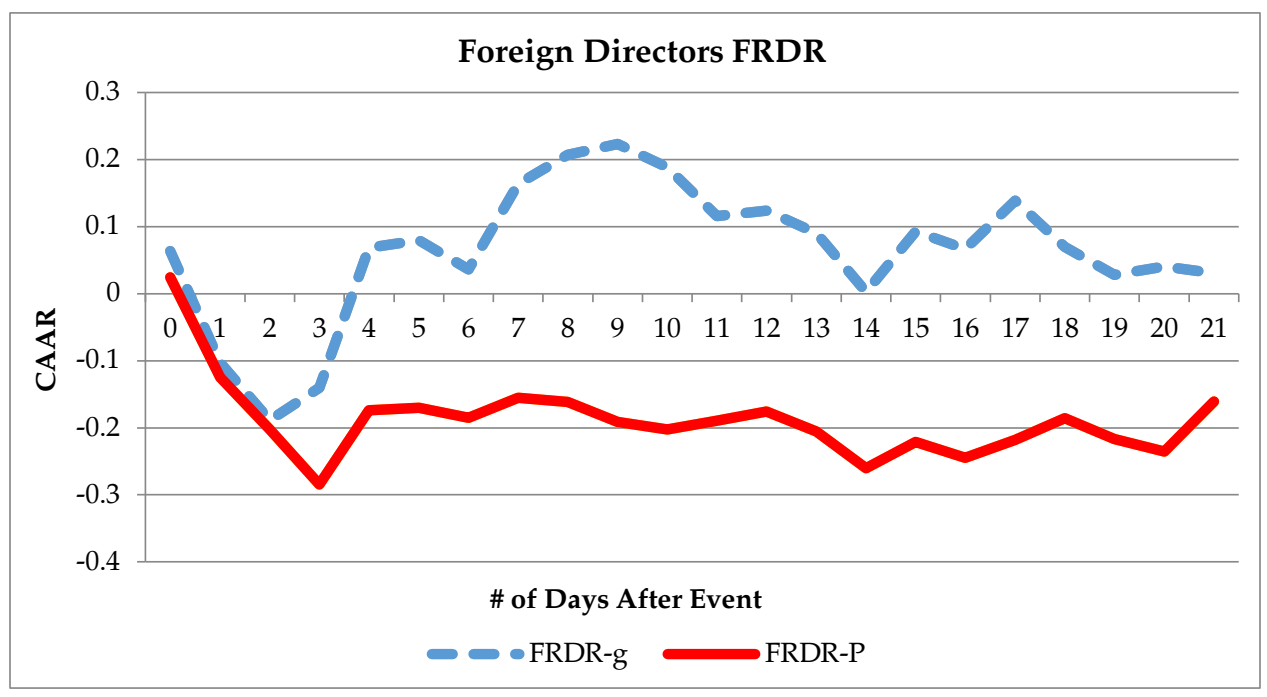


Figure 5: CAAR for Firms with Higher (INDR-G) and with Lower (INDR-P) Number of Independent Directors.

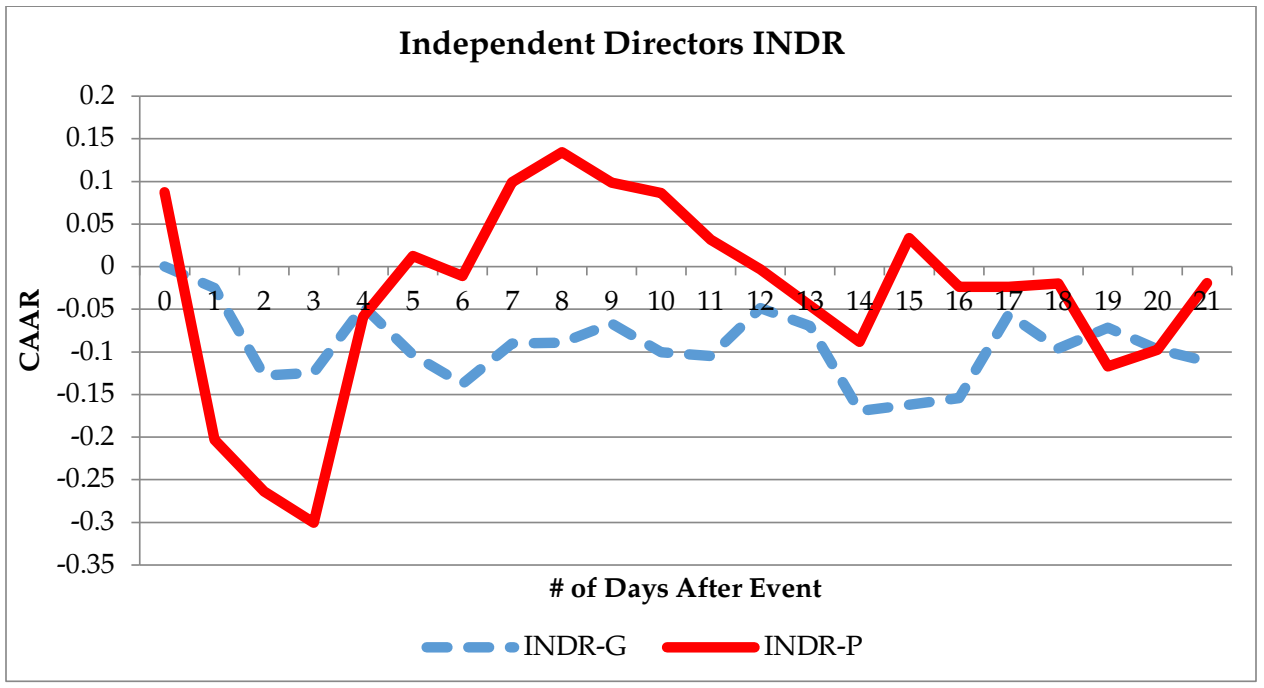

Figure 6: CAAR for Firms with Lower Family Ownership (FMOW-G) and Higher Family Ownership (FMOW-P)

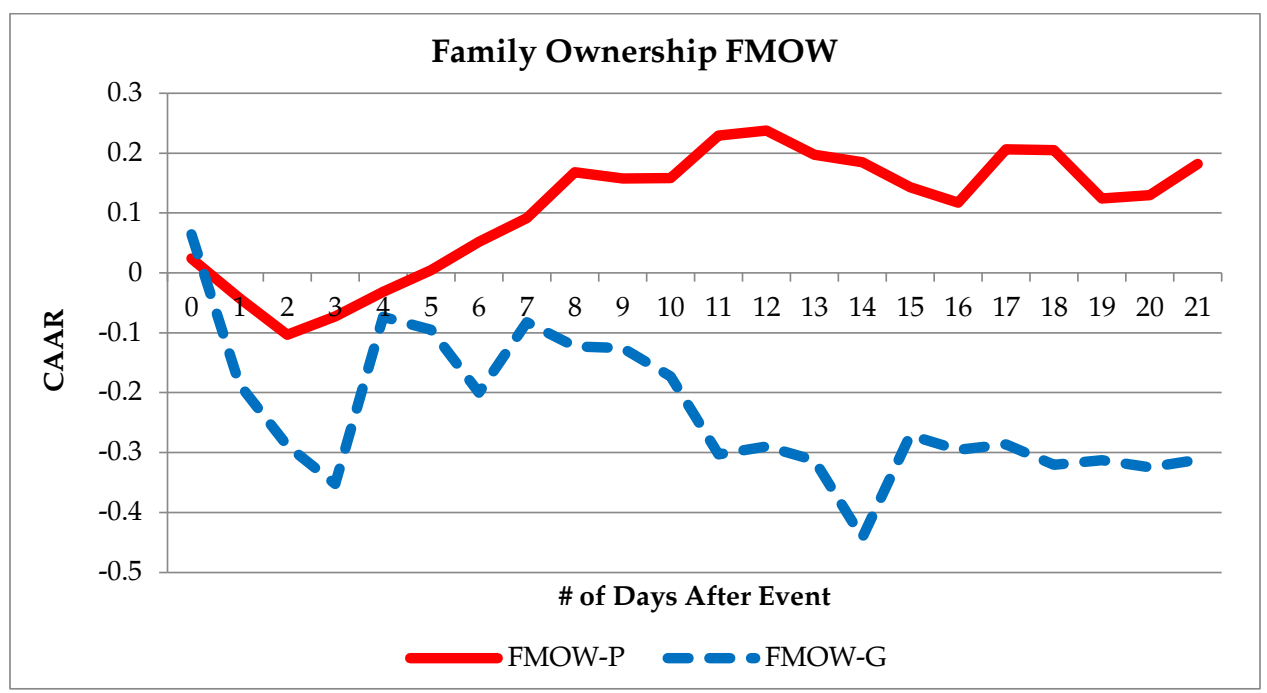


Figure 7: CAAR for Firms with Larger (INTOW-G) and Smaller (INTOW-P) Institutional Ownership

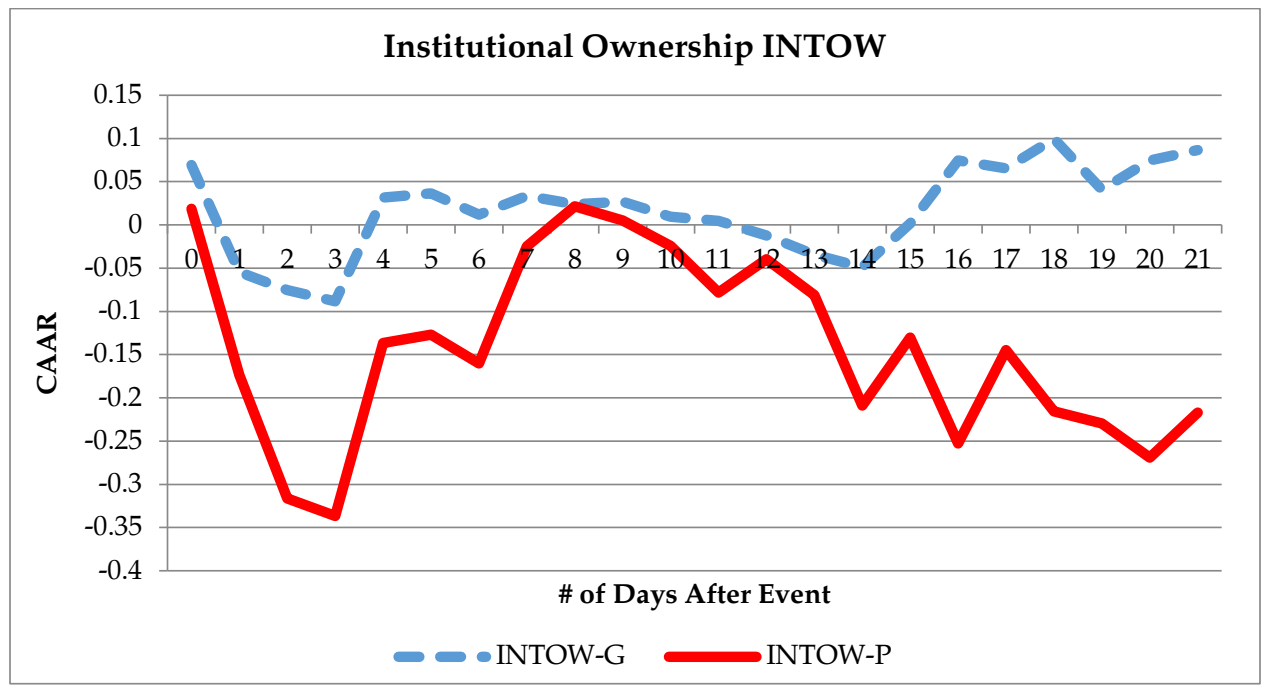

Figure 8: CAAR for Firms with Higher (BLOCK-P) and Smaller (BLOCK-G) Block Ownership

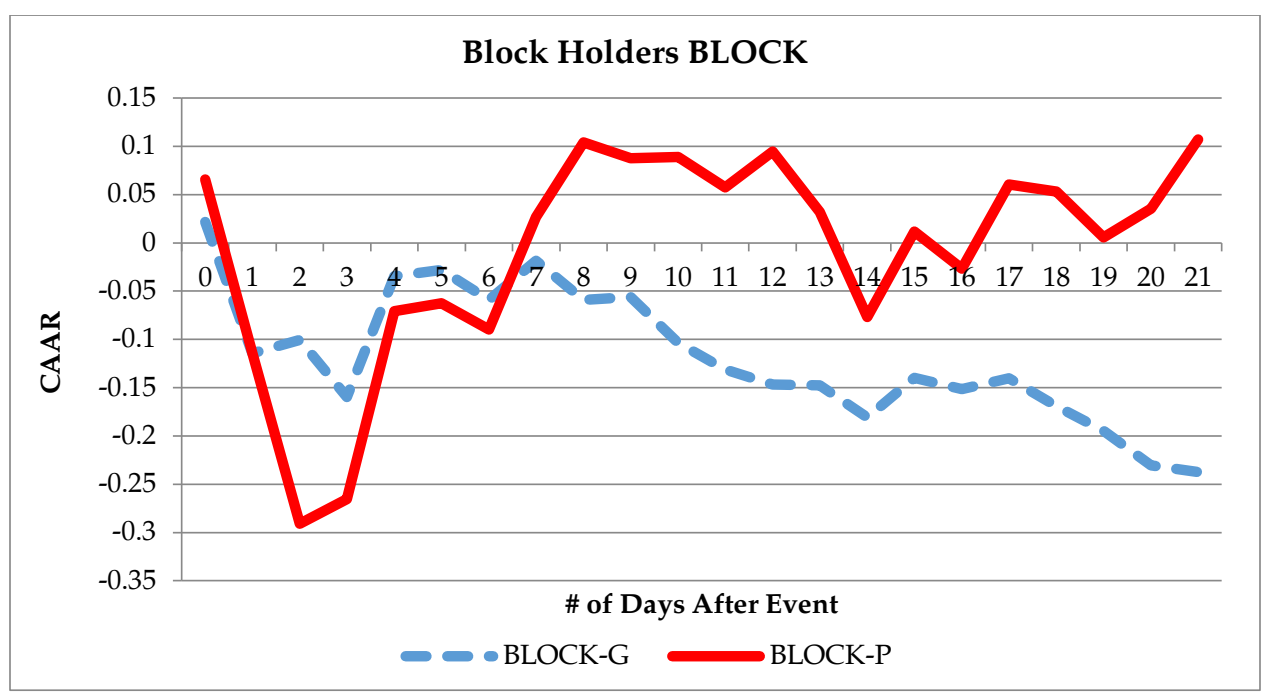


Figure 9: CAAR for Firms with CEO Duality (CECH-G) and without CEO Duality (CECH-P)

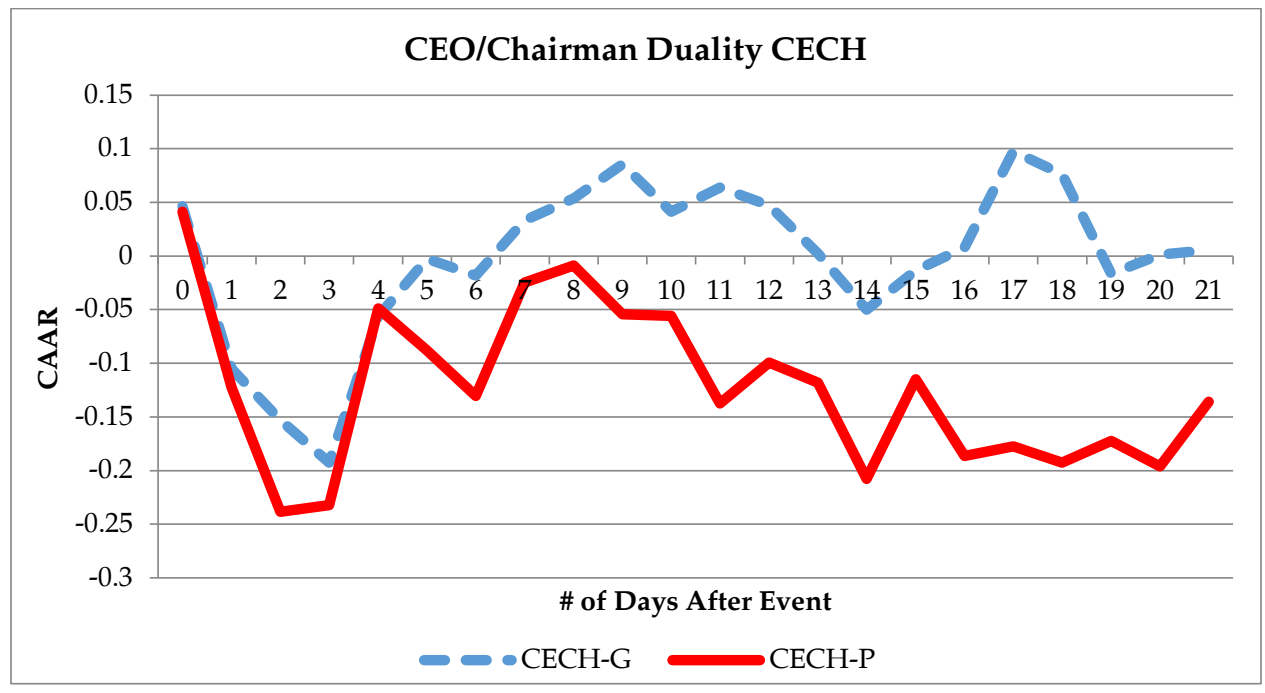

\section{Discussion and Conclusion}

The paper investigates the efficacy of corporate governance structures, and their composition in a crisis situation. Towards this objective, we have focused on the effects of the event of Benazir Bhutto's assassination on the CAAR of stocks listed on the PSX. For the pooled sample of CAAR, our findings are similar to the previous studies, in that we also observe negative abnormal returns following the event that is taken into consideration. Through this study, we have provided and introduced new insights in to the literature. With our examination, it is illustrated how corporate governance impacts that are observed during crises events. Furthermore, our segregation of conventional and unconventional corporate governance structures is new, and adds value to the research that has already been done in this discpline. This governance segregation, which digresses from the conventional strong and weak governance labels, acknowledges and recognizes that there are firms that have different governance structures, and may perform as effectively as any other firm. Other than this, we have drawn support for our the unconventional results from the literature on family-owned businesses that appear to be better managed, and perform better.

When analyzing the firm CAARs for each governance mechanism during a political and financial market crisis, we have found that firms with BIG-4 auditors experience negative returns, as compared to firms 
without BIG-4 auditors. thissuggests that the cautious and conservative approach of these auditors may impede the proactive market responses required during a crisis. However, for the conventional governance grouping in respect of foreign directors and institutional shareholding, we observe positive returns during a crisis, while CEO duality provides a smaller, negative CAAR.

In unconventionally governed firms where family ownership and block shareholding is higher, a higher CAAR is observed. This argument is supported by some researchers (Anderson \& Reeb, 2003; Carney, 2005) who contend that firms that have less diversified ownership, have a competitive edge on their rivals. It gives them an advantage in decision making in situations where there are time constraints. Similarly, a higher proportion of independent directors perform worse than a board having a lower level of independence during a crisis.

From the findings we conclude that firms which are controlled by family members were less vulnerable during the days following the assassination. These findings indicate that firms with strict governance mechanisms might not be proactive enough in decision making in the wake of unanticipated event. Moreover, our results suggest that firms having less diversified ownership and governance mechanism are less vulnerable to such unanticipated events. There are two reasons that support these findings: first, strict governance mechanisms and resultant cautious and conservative approach may not allow firms to take timely and proactive decisions during these situations; secondly, this could stem from a lower chance of existing agency problems, as family owners would be working for the protection of their own wealth during these events. In our comparison of conventionally and unconventionally governed firms, we conclude that a larger number of independent directors, and a smaller percentage of block holders result in a reduction in the CAAR values, while a larger foreign directorship and a larger institutional ownership positively impact the CAAR. The Big-4 external auditors, independent directorship and more diversified ownership hinder the performance of the firm in its response to a crisis event.

Overall the results show that conventionally-governed firms record a lower CAAR, as compared to unconventionally governed firms when it comes to the response to crisis events. This indicates that the conventional corporate governance structures may not be equipped to be flexible in the face of a crisis. This may also be due to an over-cautious and conservative approach, which works well during normal periods, but is a handicap 
during crises. Therefore, we suggest that there could be some flexibility or a contingency committee in the corporate governance structure that may provide a cushion during a crisis, and have the freedom to operate independently, in order to respond in a timely and dynamic manner as required.

This is the first study (to the knowledge of the authors) both nationally and globally that examines the corporate governance risk management responses during a crisis. And the perspective of conventional and unconventional governance provides new insights to the existing literature. It extends research in the area of corporate governance and capital markets. These findingsh have important implications for regulators and the management in their choice and restructuring of corporate governance framework. 


\section{References}

Adams, R. B., \& Mehran, H. (2003). Is corporate governance different for bank holding companies? Economic Policy Review, 9(1), 123-142.

Ali, H., Qingshi, W., Memon, Z. A., Baz, K., \& Ali, I. (2017). How Different Terrorist Attacks Affect Stock Returns Evidence from Pakistan Stock Exchange. International Research Journal of Finance and Economics, September 2017 (163), 103-120.

Anderson, R. C., \& Reeb, D. M. (2003). Founding-family ownership and firm performance: evidence from the S\&P 500. The Journal of Finance, 58(3), 1301-1328.

Barontini, R. \& Caprio, L. (2006). The effect of family control on firm value and performance: Evidence from Continental Europe. European Financial Management, 12 (5), 689-723.

Barros, C. P., \& Gil-Alana, L. A. (2009). Stock market returns and terrorist violence: evidence from the Basque Country. Applied Economics Letters, 16(15), 1575-1579.

Beltratti, A., \& Stulz, R. M. (2009). Why did some banks perform better during the credit crisis? A cross-country study of the impact of governance and regulation. National Bureau of Economic Research, NBERWorking Paper Series, 15180, 1-33.

Brown, S., \& Warner, B. (1985). Using daily stock returns: The case of event studies. Journal of Financial Economics, 14(1), 3-31.

Carney, M. (2005). Corporate governance and competitive advantage in familycontrolled firms. Entrepreneurship theory and practice, 29(3), 249-265.

Erkens, D. H., Hung, M., \& Matos, P. (2012). Corporate governance in the 20072008 financial crisis: Evidence from financial institutions worldwide. Journal of Corporate Finance, 18(2), 389-411.

Farber, D. (2005). Restoring trust after fraud: Does corporate governance matter? The Accounting Review, 80 (2), 539-561.

Feinberg, R. M., (1975). Profit maximization vs. utility maximization. Southern Economic Journal, 42(1), 130-131.

Hassan, S. A., Mahmood, A., Ahmed, A., \& Abbas, S. F. (2014). Impact of terrorism on Karachi Stock Exchange: Pakistan. Journal of Basic and Applied Scientific Research, 4(7), 182-191. 
Javid, A. Y., \& Iqbal, R. (2008). Ownership concentration, corporate governance and firm performance: Evidence from Pakistan. The Pakistan Development Review, 47(4), 643-659.

Khurrana, I., \& Raman, K., (2004). Litigation risk and the financial reporting credibility of big 4 versus non-big 4 audits: Evidence from AngloAmerican countries. The Accounting Review, 79 (2), 473-495.

Kirkpatrick, G. (2009). The corporate governance lessons from the financial crisis. OECD Journal: Financial Market Trends, (2009)1, 61-87.

Kothari, S. P., \& Warner, J. B. (2007). Econometrics of event studies. Handbook of Empirical Corporate Finance, 1, 3-36.

Lang, M., \& Maffett, M. (2011). Transparency and liquidity uncertainty in crisis periods. Journal of Accounting and Economics, 52(2-3), 101-125.

Lemmon, M. \& Lins, K. (2003). Ownership structure, corporate governance, and firm value: Evidence from the East Asian financial crisis. The Journal of Finance, 58 (4), 1445-1468.

Lin, Y. \& Fu, X (2017). Does institutional ownership influence firm performance? Evidence from China. International Review of Economics and Finance, May 2017, (49), 17-57

Livemint, 2017. India's corporate governance challenge. https://www.livemint.com/Companies/1MW7bYVYjyv4eiDytu2ZQN/India s-corporate-governance-challenge.html

Masulis, R., Wang, C. \& Xie, F. (2012). Globalizing the boardroom-The effects of foreign directors on corporate governance and firm performance. Journal of Accounting and Economics, 53 (3), 527-554.

Nazir, S. M., Younus, H., Kaleem, A., \& Anwar, Z. (2014). Impact of political events on stock market returns: Empirical evidence from Pakistan. Journal of Economic and Administrative Sciences, 30(1), 60-78.

Suleman, M. T. (2012). Stock market reaction to good and bad political news. Asian Journal of Finance $\mathcal{E}$ Accounting, 4(1), 299-312.

Taimur, M., \& Khan, S. (2015). Impact of Political and Catastrophic Events on Stock Returns. VFAST Transactions on Education and Social Sciences, 6(1), 21-32. 
Appendix 1

\section{CAAR Calculations}

Calculating CAAR for the stocks: it

$$
E(R i t)=\alpha i+\beta i R m t+\varepsilon \quad \ldots \ldots . .
$$

In the above equation, equation 1 , market model is defined to determine the expected return ' $E(R i t)$ 'of a stock. Using the equation 1 , market return ' $R m t^{\prime}$ ' for the same period as that of estimation window of a stock is taken and regression is run to find-out the daily expected returns.

$$
\text { ARit }=(\text { ACRit }-E i) \quad \ldots \ldots \ldots \ldots . . .
$$

After calculating the expected returns of a stock, abnormal returns 'ARit' can be computed using the above equation 2, which we get as a result of expected return subtracting the abnormal return of a particular day.

$$
A A B R t=\sum_{i}^{n} A B R i t / n \quad \ldots \ldots \ldots
$$

As we have multiple stocks, so we calculate Average Abnormal Return 'AABRt' as the sum of all the abnormal returns on a particular day. This is shown in the equation (3) above.

$$
\text { CAARt }=\sum_{t} A A B R t \quad \ldots \ldots \ldots
$$

At last, the CAAR is obtained using the equation (4) above, as sum of AABR in a rolling manner. In the analysis window we take 5 days for the examination of CAAR. 
Appendix 2

\section{Definition of Variables}

\begin{tabular}{|c|c|c|c|c|}
\hline Variable & $\begin{array}{c}\text { Conventional } \\
\text { Governance } \\
\text { Definition }\end{array}$ & $\begin{array}{l}\text { Unconventional } \\
\text { Governance } \\
\text { Definition }\end{array}$ & Measure & Research \\
\hline BIG4 & $\begin{array}{l}\text { If the auditors } \\
\text { of a firm } \\
\text { belongs from } \\
\text { big } 4 \text { auditors. }\end{array}$ & $\begin{array}{l}\text { If the auditors are } \\
\text { other than BIG-4. }\end{array}$ & $\begin{array}{l}\text { Dummy Variable, } \\
1 \text { for } \\
\text { Conventional, } 0 \\
\text { for } \\
\text { Unconventional }\end{array}$ & $\begin{array}{l}\text { Khurrana } \\
\text { and Raman } \\
\text { (2004) }\end{array}$ \\
\hline FRDR & $\begin{array}{l}\text { If there are } \\
\text { foreign } \\
\text { directors in } \\
\text { the BOD. }\end{array}$ & $\begin{array}{l}\text { If there are no } \\
\text { foreign directors. }\end{array}$ & $\begin{array}{l}\text { Dummy, } 1 \text { for } \\
\text { Conventional, } 0 \\
\text { for } \\
\text { Unconventional }\end{array}$ & $\begin{array}{l}\text { Massulis, } \\
\text { Wang and } \\
\text { Xie (2012) }\end{array}$ \\
\hline INDR & $\begin{array}{l}\text { If the } \\
\text { representation } \\
\text { of } \\
\text { independent } \\
\text { directors in } \\
\text { BOD is above } \\
\text { the mean of } \\
\text { overall } \\
\text { sample. }\end{array}$ & $\begin{array}{l}\text { If the } \\
\text { representation of } \\
\text { Independent } \\
\text { directors is less } \\
\text { than the sample } \\
\text { mean. }\end{array}$ & $\begin{array}{l}\text { Mean, } 1 \text { for } \\
\text { Conventional, } 0 \\
\text { for } \\
\text { Unconventional }\end{array}$ & $\begin{array}{l}\text { Farber } \\
(2005)\end{array}$ \\
\hline FMOW & $\begin{array}{l}\text { If the family } \\
\text { ownership in a } \\
\text { firm is below } \\
\text { the mean of } \\
\text { sample. }\end{array}$ & $\begin{array}{l}\text { If the family } \\
\text { holdings in a firm } \\
\text { is more than the } \\
\text { sample mean. }\end{array}$ & $\begin{array}{l}\text { Mean, } 1 \text { for } \\
\text { Conventional, } 0 \\
\text { for } \\
\text { Unconventional }\end{array}$ & $\begin{array}{l}\text { Barontini \& } \\
\text { Caprio } \\
\text { (2006) }\end{array}$ \\
\hline INOW & $\begin{array}{l}\text { If the } \\
\text { institutional } \\
\text { holdings in a } \\
\text { firm is greater } \\
\text { than the } \\
\text { sample mean. }\end{array}$ & $\begin{array}{l}\text { If the institutional } \\
\text { holdings less than } \\
\text { the sample mean. }\end{array}$ & $\begin{array}{l}\text { Mean, } 1 \text { for } \\
\text { Conventional, } 0 \\
\text { for } \\
\text { Unconventional }\end{array}$ & $\begin{array}{l}\text { Lin et al. } \\
\text { (2013) }\end{array}$ \\
\hline BLOCK & $\begin{array}{l}\text { If block } \\
\text { holders are } \\
\text { less than the } \\
\text { sample mean. }\end{array}$ & $\begin{array}{l}\text { If the number of } \\
\text { block holders in a } \\
\text { firm are more } \\
\text { than the sample } \\
\text { mean. }\end{array}$ & $\begin{array}{l}\text { Mean, } 1 \text { for } \\
\text { Conventional, } 0 \\
\text { for } \\
\text { Unconventional }\end{array}$ & $\begin{array}{l}\text { Lemmon \& } \\
\text { Lins (2003) }\end{array}$ \\
\hline
\end{tabular}




\begin{tabular}{|c|c|c|c|c|}
\hline Variable & $\begin{array}{c}\text { Conventional } \\
\text { Governance } \\
\text { Definition }\end{array}$ & $\begin{array}{c}\text { Unconventional } \\
\text { Governance } \\
\text { Definition }\end{array}$ & Measure & Research \\
\hline $\mathrm{CECH}$ & $\begin{array}{l}\text { If CEO and } \\
\text { Chairman of } \\
\text { Board are } \\
\text { different } \\
\text { persons } \\
\text { (duality) it is } \\
\text { rated as } \\
\text { conventional } \\
\text { governance. }\end{array}$ & $\begin{array}{l}\text { If there is no } \\
\text { duality. }\end{array}$ & $\begin{array}{l}\text { Dummy, } 1 \text { for } \\
\text { Conventional, } 0 \\
\text { for } \\
\text { Unconventional }\end{array}$ & $\begin{array}{l}\text { Farber } \\
(2005)\end{array}$ \\
\hline POOLED & $\begin{array}{l}\text { Taking full } \\
\text { sample }\end{array}$ & Taking full sample & & \\
\hline
\end{tabular}


Appendix 3

\section{Levene's Test For Equality of Variance and Two Tailed T-Test or Equality of Means in the Characteristics of Conventional and Unconventionally Governed Firms}

\begin{tabular}{|c|c|c|c|c|c|c|c|c|}
\hline & & $\begin{array}{l}\text { Leven } \\
\text { for Equ } \\
\text { Vari }\end{array}$ & $\begin{array}{l}\text { S Test } \\
\text { lity of } \\
\text { aces }\end{array}$ & & t-tes & for Equa & lity of Means & \\
\hline & & F & Sig. & $\mathrm{T}$ & $\mathrm{df}$ & $\begin{array}{l}\text { Sig. (2- } \\
\text { tailed) }\end{array}$ & $\begin{array}{c}\text { Mean } \\
\text { Difference }\end{array}$ & $\begin{array}{c}\text { Std. Error } \\
\text { Difference }\end{array}$ \\
\hline $\begin{array}{l}\text { CG } \\
\text { Pooled }\end{array}$ & $\begin{array}{l}\text { Equal variances } \\
\text { assumed }\end{array}$ & 51.855 & .000 & -8.290 & 42 & .000 & -.71517 & .08627 \\
\hline & $\begin{array}{l}\text { Equal variances } \\
\text { not assumed }\end{array}$ & & & -8.290 & 21.370 & .000 & -.71517 & .08627 \\
\hline BIG 4 & $\begin{array}{l}\text { Equal variances } \\
\text { assumed }\end{array}$ & .204 & .654 & -5.919 & 42 & .000 & -.13072 & .02208 \\
\hline & $\begin{array}{l}\text { Equal variances } \\
\text { not assumed }\end{array}$ & & & -5.919 & 41.958 & .000 & -.13072 & .02208 \\
\hline FRDR & $\begin{array}{l}\text { Equal variances } \\
\text { assumed }\end{array}$ & 3.753 & .059 & 9.841 & 42 & .000 & .25156 & .02556 \\
\hline & $\begin{array}{l}\text { Equal variances } \\
\text { not assumed }\end{array}$ & & & 9.841 & 33.664 & .000 & .25156 & .02556 \\
\hline INDR & $\begin{array}{l}\text { Equal variances } \\
\text { assumed }\end{array}$ & 8.806 & .005 & -2.376 & 42 & .022 & -.06181 & .02601 \\
\hline & $\begin{array}{l}\text { Equal variances } \\
\text { not assumed }\end{array}$ & & & -2.376 & 26.988 & .025 & -.06181 & .02601 \\
\hline FMOW & $\begin{array}{l}\text { Equal variances } \\
\text { assumed }\end{array}$ & .669 & .418 & -10.126 & 42 & .000 & -.33944 & .03352 \\
\hline & $\begin{array}{l}\text { Equal variances } \\
\text { not assumed }\end{array}$ & & & -10.126 & 41.083 & .000 & -.33944 & .03352 \\
\hline INTOW & $\begin{array}{l}\text { Equal variances } \\
\text { assumed }\end{array}$ & 10.607 & .002 & 6.245 & 42 & .000 & .15895 & .02545 \\
\hline & $\begin{array}{l}\text { Equal variances } \\
\text { not assumed }\end{array}$ & & & 6.245 & 30.508 & .000 & .15895 & .02545 \\
\hline BLOCK & $\begin{array}{l}\text { Equal variances } \\
\text { assumed }\end{array}$ & 3.011 & .090 & -3.957 & 42 & .000 & -.10974 & .02774 \\
\hline & $\begin{array}{l}\text { Equal variances } \\
\text { not assumed }\end{array}$ & & & -3.957 & 35.396 & .000 & -.10974 & .02774 \\
\hline $\mathrm{CECH}$ & $\begin{array}{l}\text { Equal variances } \\
\text { assumed }\end{array}$ & .181 & .672 & 5.368 & 42 & .000 & .12072 & .02249 \\
\hline & $\begin{array}{l}\text { Equal variances } \\
\text { not assumed }\end{array}$ & & & 5.368 & 41.990 & .000 & .12072 & .02249 \\
\hline
\end{tabular}

